\title{
PKM Strategi Membangun Bisnis Yang Kuat Melalui Pendampingan Pada Komunitas Kebon Pala Berseri Kecamatan Makasar Jakarta Timur
}

\author{
Eka Dyah Setyaningsih ${ }^{1}$, Ida Zuniarti ${ }^{2}$, Titik Misriati $^{3}$ \\ ${ }^{1,2}$ Akuntansi, Universitas Bina Sarana Informatika \\ 1eka.edy@bsi.ac.id, ${ }^{2}$ ida.idz@bsi.ac.id \\ ${ }^{3}$ Sistem Informasi, Universitas Bina Sarana Informatika \\ 3titik.tmi@bsi.ac.id
}

\begin{abstract}
Small and Medium Enterprises in the Kebon Pala Berseri Business Community are still not maximal in developing businesses in the field of processed foods, herbal medicines, and handicrafts. Therefore, there is a need for entrepreneurship training to improve the soft skills of community service participants to have a strong mentality in running a business. In addition to training, assistance is also provided to partners to be able to run a business and build a strong business to increase the productivity of the business being run. Based on the results of the implementation of training and mentoring, it can be concluded that partner understanding increased by $77 \%$.
\end{abstract}

Keywords: Balance, Efficiency, Station, Weight

\begin{abstract}
ABSTRAK
Usaha Kecil dan Menengah yang terdapat di Komunitas Usaha Kebon Pala Berseri masih belum maksimal dalam mengembangkan usaha di bidang makanan olahan, obat herbal, dan kerajinan tangan. Oleh sebab itu, perlu adanya pelatihan tentang kewirausahaan untuk meningkatkan kemampuan soft skill dari peserta pengabdian masyarakat agar memiliki mental yang kuat dalam menjalankan usaha. Selain pelatihan, dilakukan juga pendampingan terhadap mitra agar mampu menjalankan usaha dan membangun bisnis yang kuat untuk meningkatkan produktivitas dari usaha yang dijalankan. Berdasarkan hasil pelaksanaan pelatihan dan pendampingan, dapat disimpulkan bahwa pemahaman mitra meningkat sebanyak $77 \%$.
\end{abstract}

Kata kunci: PKM, Strategi bisnis, Pendampingan

\section{PENDAHULUAN}

Pembinaan UKM (Usaha Kecil dan Menengah) melalui pendampingan saat ini sedang digalakkan guna memperbaiki perekonomiam masyarakat. Definisi UKM menurut UndangUndang Nomor 20 Tahun 2008 Pasal 1 dalam Ariani \& Utomo (2017) adalah usaha ekonomi produktif yang berdiri sendiri, dilakukan oleh perorangan atau badan usaha yang bukan merupakan anak perusahaan atau bukan cabang perusahaan yang dimiliki, dikuasai, atau menjadi bagian, baik langsung maupun tidak langsung, dari usaha menengah atau usaha besar. Langkah awal yang dilakukan untuk memajukan perekonomian masyarakat diawali dengan perencanaan bisnis yang matang untuk menuju strategi membangun bisnis yang kuat dan memiliki daya saing. Menurut Ariani \& Utomo (2017), pengembangan UKM menjadi sangat strategis karena potensinya yang besar dalam menggerakkan kegiatan ekonomi masyarakat dan mampu menjadi tumpuan sumber pendapatan sebagian masyarakat dalam meningkatkan kesejahteraan. Seorang pelaku bisnis juga harus memiliki mental semangat yang kuat dan positif dalam menghadapi segala rintangan bisnis serta didukung dengan produk yang dihasilkan harus memiliki inovasi baru agar konsumen tertarik untuk membeli hasil produksi barang tersebut.

Penelitian sebelumnya, menurut Sakur (2011), Suandi (2011), Irdayanti (2012), dan Syahza (2013), beberapa permasalahan dalam UMKM adalah: (1) Pemasaran; (2) Modal dan pendanaan; (3) Inovasi dan pemanfaatan teknologi informasi; (4) Pemakaian bahan baku; (5) Peralatan produksi; (6) Penyerapan dan pemberdayaan tenaga kerja; (7) Rencana pengembangan usaha; dan (8) Kesiapan menghadapi tantangan lingkungan eksternal. Berdasarkan penelitian ini maka dapat 
dilihat bahwa kontribusi dan peran UMKM pada perekonomian nasional sangat berarti, namun dari sisi daya saing, banyak kelemahan dan permasalahan bagi UKM yang harus dibenahi untuk menghadapi persaingan, baik di dalam negeri maupun secara global.

Kegiatan UKM yang dibahas pada penelitian ini terdapat di daerah RPTRA Kebon Pala Jakarta Timur. RPTRA Kebon Pala terletak berbatasan dengan Kelurahan Cipinang Besar Selatan di sebelah utara, Kelurahan Halim Perdanakusuma dan Kelurahan Makasar di sebelah selatan, sebelah timur berbatasan dengan Kelurahan Cipinang Melayu dan Kelurahan Halim Perdanakusuma, dan di sebelah barat dengan Kelurahan Cililitan dan Kelurahan Cawang. Wilayah Kebon Pala, Kecamatan Makasar, Jakarta Timur yang beralamat di Jalan Kamboja RT 10/RW 01 Kode Pos 13650 merupakan daerah yang memiliki potensi usaha kecil menengah yang layak dikembangkan untuk kesejahteraan masyarakat. Salah satu yang dapat dikembangkan adalah usaha milik Ibu Marimin atau juga dikenal dengan nama usahanya "UMMI" dengan nama kelompok Matahari. Berikut ini usaha yang sedang dijalankan:

1) Usaha yang memiliki keunikan bahan dasar Aloe vera atau lidah buaya yang diolah sedemikian rupa menjadi makanan kecil seperti sistik lidah buaya, kue bawang, minuman segar lidah buaya, kue onde riang, kue onde mini, akar kelapa.

2) Minuman instan yang terbuat dari bahan alami seperti kunyit putih, jahe, kencur, temu lawak dan lainnya yang berkhasiat untuk kesehatan badan secara alami

3) Selain itu kerajian tangan juga dihasilkan berupa manik-manik yang dijadikan tas, tempat tissue dan lain-lain.

Pada usaha ini, Ibu Marimin selaku pemilik usaha membudidayakan penanaman aloe vera di kebun dan ada juga rumah masyarakat sekitar. Apabila ditanam di rumah masyarakat sekitar maka pemilik kebun dapat menjual lidah buaya ke usaha milik Ibu Marimin untuk diolah lagi dan menjadi makanan kecil maupun minuman. Beberapa hal yang kami lihat dari hasil survei ini ada beberapa hal yang harus dibenahi yaitu :

1. Alat produksi yang digunakan seperti blender kering dengan ukuran yang besar belum ada sehingga akan memperlambat pesanan yang ada.

2. Sumber daya manusia, masih ada kelompok masyarakat yang menjalankan usaha ini seadanya tanpa ada pengelolaan dan strategi yang kuat dalam usaha

3. Rumah produksi berada di tempat padat penduduk maka perlu ada penunjuk arah yang jelas.

Berdasarkan analisis situasi yang telah diuraikan maka untuk mengatasi permasalahan ini maka perlu ada solusi. Pada kegiatan pengabdian masyarakat ini ditawarkan solusi diantaranya adalah :

1. Pengadaan adanya blender kering untuk mempermudah produksi

2. Memberikan pelatihan kewirausahaan mengenai "Tips Mengelola Usaha" dan "Strategi Membangun Bisnis Yang Kuat"

3. Penggunaan inovasi teknologi berupa google maps agar mudah penunjuk arah tempat rumah produksi.

Solusi ini diberikan karena melihat potensi hasil alam yang dihasilkan dari Aloe vera yang bisa dikembangkan produktivitasnya secara berkesinambungan di wilayah Kebon Pala serta dapat menambah penghasilan masyarakat sekitar.

\section{METODE PELAKSANAAN}

Kegiatan pengabdian masyarakat di Kebon Pala ini bertujuan untuk pengelolaan usaha dan membangun bisnis yang kuat untuk meningkatkan produktivitas Aloe vera serta memperbaiki peralatan produksi yang masih kurang untuk menunjang kelancaran usaha. Metode yang digunakan dalam PKM sebagai berikut :

1) Pelatihan dan Penerapan Tips Mengelola Usaha

Pelatihan ini dipilih dikarena untuk mengembangkan usaha dan meningkatkan produktifitas dari bahan dasar Aloe vera, tanamanan herbal, serta manik-manik kerjainan tangan untuk dijadikan tas, tempat tissue dan lain-lain. Selama ini beberapa masyarakat masih berpindah- 
pindah dalam memilih jenis usaha dan cenderung tidak sabar untuk mengelola lebih lanjut dari usaha yang sudah ada. Maka disini memberikan pelatihan secara soft skill supaya secara mental para pelaku usaha lebih tangguh dan kuat dalam menghadapai tantangan usaha

2) Pelatihan dan Penerapan Strategi Membangun Bisnis yang Kuat

Metode ini dipilih bertujuan agar masyarakat memiliki strategi dipasar bagaimana supaya diterima dan laku terjual dipasar. Memiliki ciri khas tersendiri dari makanan, minuman serta kerajinan tangan yang dihasilkan dari manik-manik. Hal ini harus memiliki rencana bisnis yang matang agar usaha ini dapat menyesuaikan dengan keadaan pasar yang memiliki inovasi terbaru

3) Pelatihan menampilkan Google Maps local business

Metode ini digunakan karena mengingat lokasi usaha ini merupakan kawasan padat penduduk maka untuk promosi akan lebih baik diberikan Google Maps jika orang ingin membeli makan khas dari Aloe vera baik minuman, makanan atau hasil kerajinan tangan menjadi lebih mudah dikenal pembeli.

4) Memberikan output berupa blender kering dengan ukuran yang lebih besar untuk mempercepat proses produksi.

\section{HASIL DAN PEMBAHASAN}

Kegiatan pelaksanaan pengabdian masyarakat dilakukan di RPTRA Kebon Pala setiap hari Sabtu. Tim pengabdian masyarakat melakukan observasi dan melakukan komunikasi tentang maksud serta tujuan dari tim pengabdian masyarakat untuk melakukan pelatihan dan pendampingan melalui kegiatan PKM ini agar lebih berkembang UKM di lingkungan RPTRA Kebon Pala Berseri dengan menggali potensi yang sudah ada. Selain observasi, ini tim pengabdian masyarakat juga mengajukan persetujuan untuk melakukan pengabdian masyarakat ke RPTRA Kebon Pala Berseri yang merupakan wadah masyarakat dalam memasarkan hasil UKM dari usaha Ibu Marimin dengan kelompok matahari.
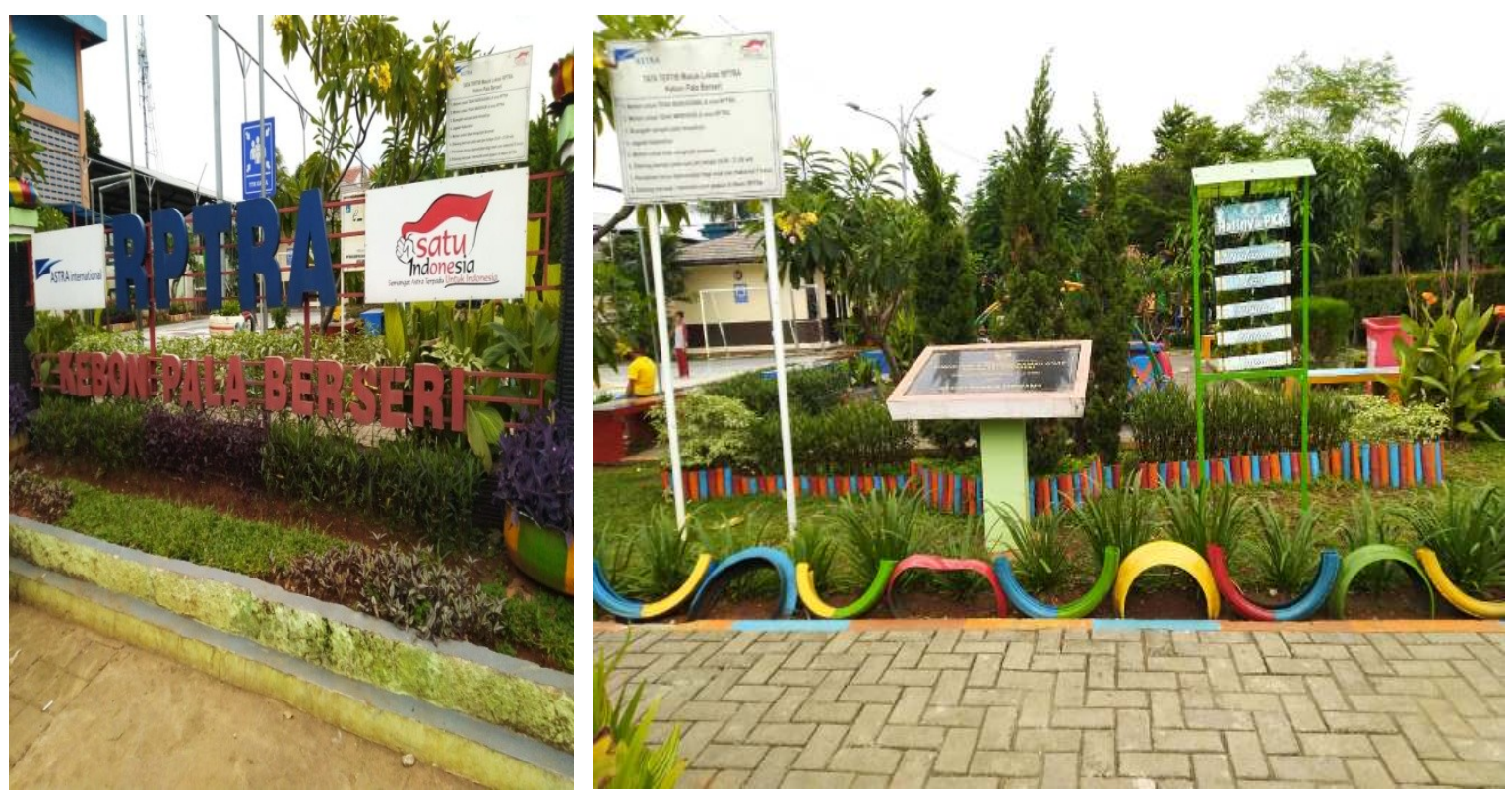

Gambar 1. Lokasi RPTRA Kebon Pala Berseri 

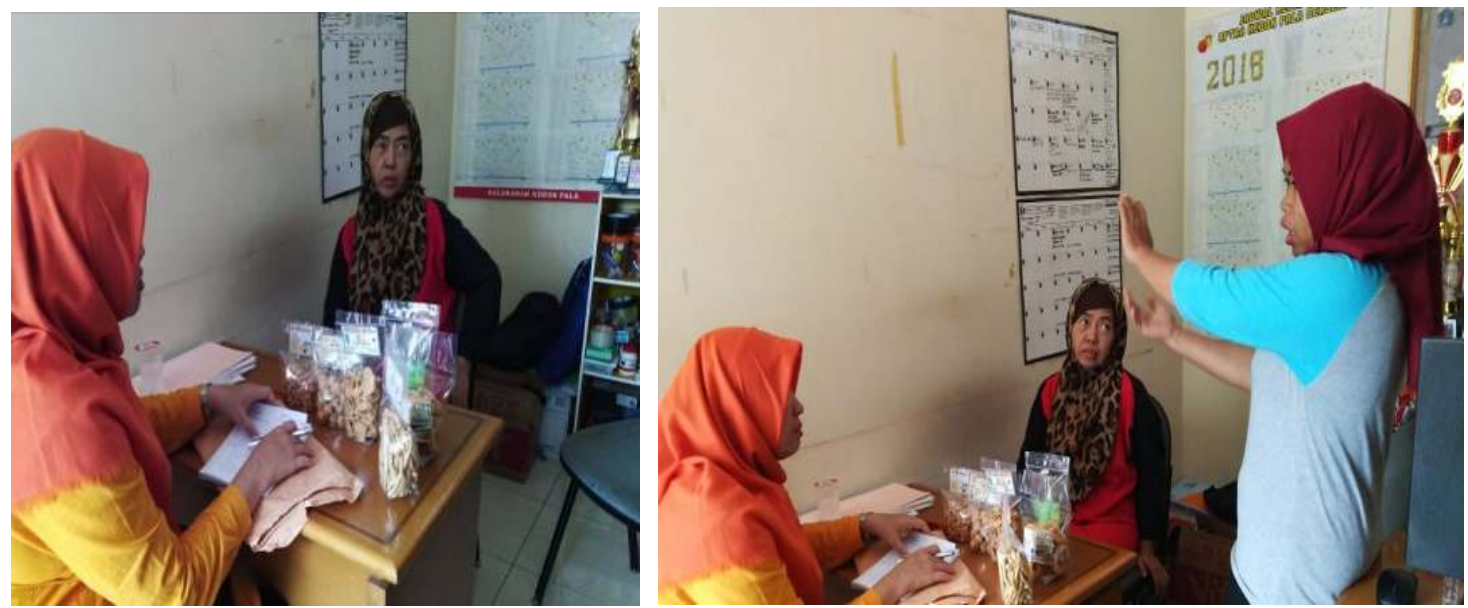

Gambar 2. Observasi ke RPTRA Kebon Pala

Pada waktu observasi, tim pengabdian masyarakat berdialog langsung dengan Ibu Tuti dan Ibu Nia selaku pengelola kegiatan UKM di usaha Ibu Marimin. Tim pengabdian masyarakat diberikan arahan dan petunjuk mengenai usaha Aloe vera, minuman herbal instan serta kerajinan manik-manik yang dipajang hasilnya di RPTRA Kebon Pala Berseri. Setelah tim pengabdian masyarakat berdialog dengan ibu-ibu pengelola RPTRA ini langkah tim pengabdian masyarakat selanjutnya untuk observasi dan bertemu langsung Ibu Marimin sebagai pelaku usaha ini.

Pada minggu berikutnya, tim pengabdian masyarakat didampingi dengan pihak RPTRA Kebon Pala Berseri melakukan silahturahmi dan survei ke rumah produksi milik Ibu Marimin untuk mengenal produksi Ibu Marimin secara langsung. Tim pengabdian masyarakat disambut dengan ramah oleh Ibu Marimin serta beliau tidak segan-segan berbagi pengalaman menjalankan usaha ini bersama masyarakat sekitar Kebon Pala dalam memberdayakan tumbuhan Aloe vera (lidah buaya). Jadi tumbuhan Aloe vera ini dibudidayakan di kebun di sekitar pekarangan rumah Ibu Marimin serta halaman rumah warga setempat yang ikut bergabung dengan Ibu Marimin dalam menjalankan usahanya. Hasil dari Aloe vera yang sudah layak diolah maka akan dibeli untuk dijadikan olahan minuman atau makanan kecil. Selain itu masyarakat sekitar juga ikut membantu Ibu Marimin dalam menjalankan usaha Aloe vera tersebut, dari yang menanam dirumah masyarakat masing-masing, bagian administrasi, produksi sampai packaging serta pemasaran Ibu Marimin mengerahkan masyarakat sekitar untuk bersama-sama memberdayakan lingkungan Kebon Pala untuk menjadi UKM yang bisa berpotensi lebih baik dan berdaya saing ditengah persaingan yang terus meningkat.

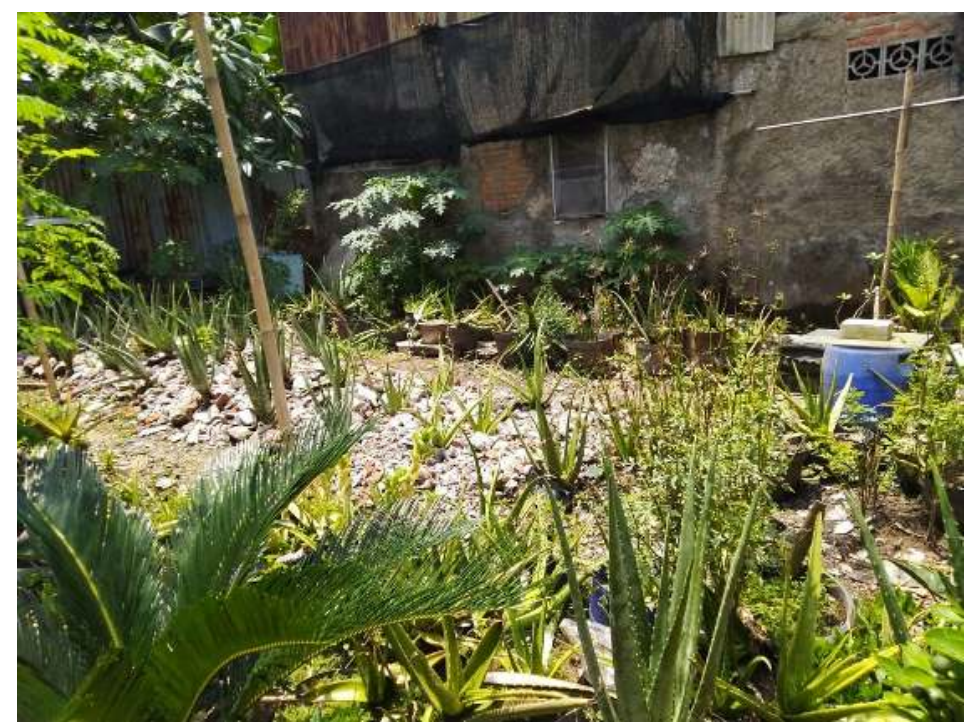

Gambar 3. Kebun Aloevera 

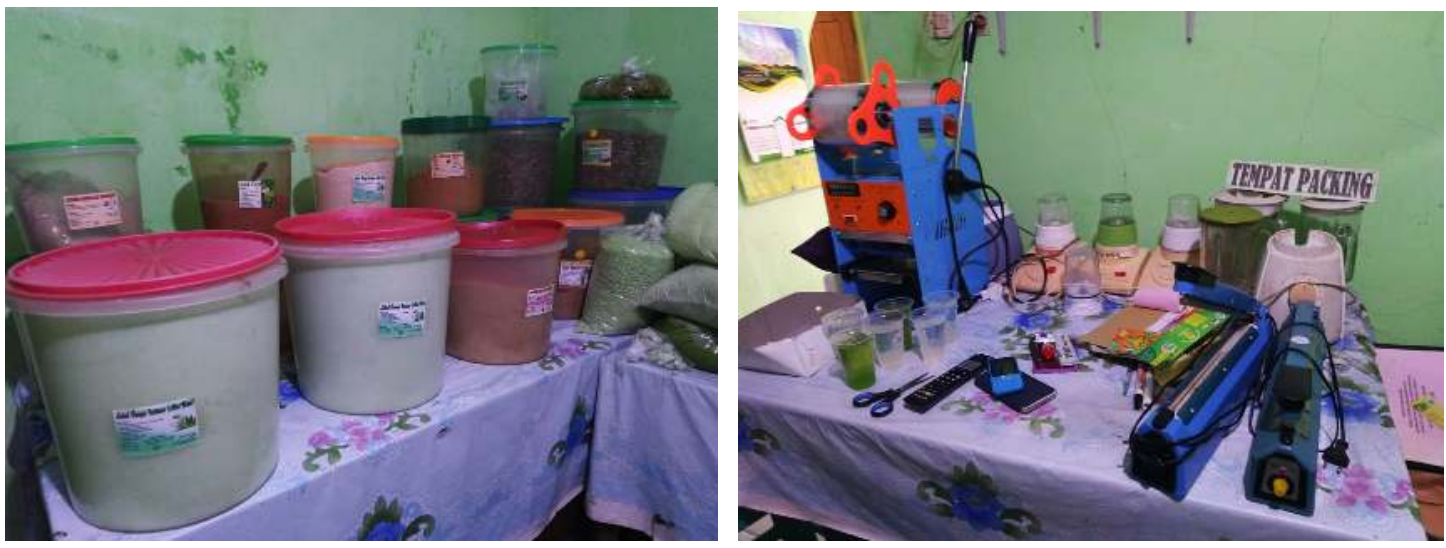

Gambar 4 Berkunjung ke Tempat Produksi Aloe vera

Dari kunjungan tim pengabdian masyarakat ke rumah produksi milik Ibu Marimin banyak hal yang dapat dipelajari dari sini. Bahwa usaha ini dibangun atas kerjasama bu Marimin dengan masyarakat sekitar maka dari warga untuk warga sehingga dapat mensejahterakan semua. Tempat produksi aloe vera terdiri dari beberapa bagian untuk administrasi, produksi dan packaging. Setelah pengecekan pada saat survei ternyata Ibu Marimin masih ada yang kurang dalam alat produksi, yaitu salah satunya alat blender kering yang digunakan untuk menggiling minuman instan yang terbuat dari kunyit, jahe, dan aloe vera.

Program Kemitraan Masyarakat ini dilaksanakan dengan pendekatan pelatihan dan pendampingan terhadap UKM di RPTRA Kebon Pala Berseri. Tujuan dari pelatihan dan pendampingan di bidang kewirausahaan ialah untuk meningkatkan pengetahuan tentang kewirausahaan terutama tentang Tips Mengelola Usaha dan Strategi Membangun Bisnis yang Kuat. Kegiatan pelatihan dilakukan di RPTRA Kebon Pala Berseri.

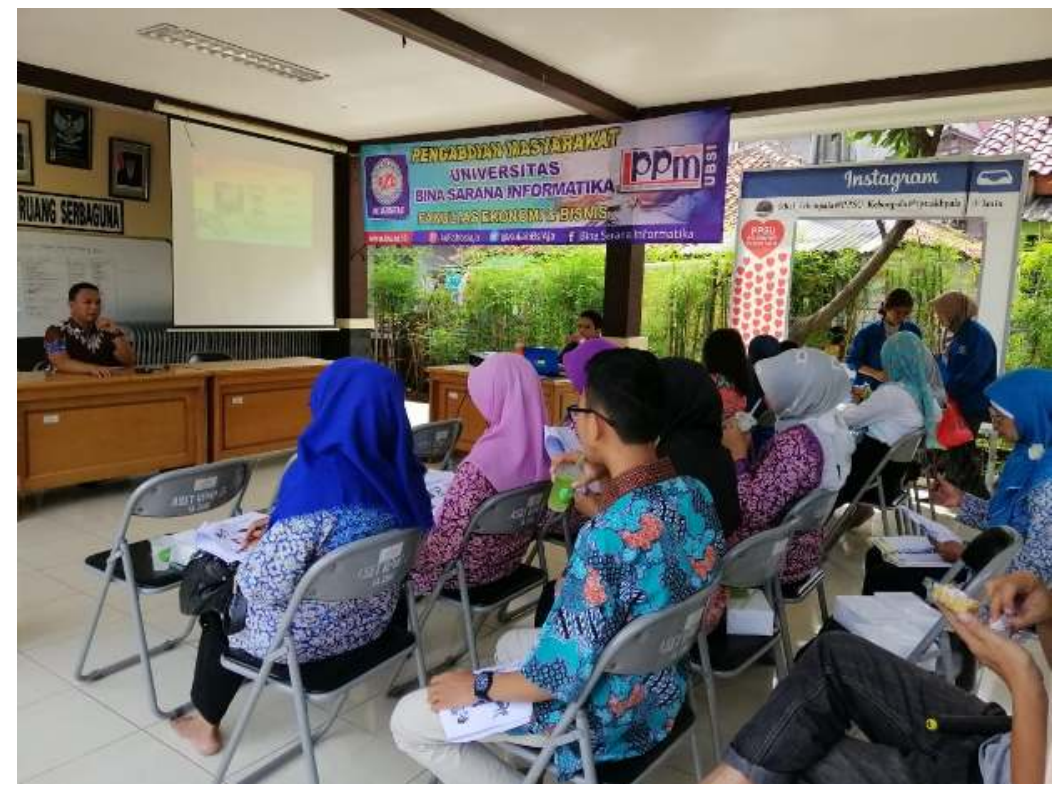

Gambar 5. Pelatihan Kewirausahaan

Selanjutnya, narasumber memberikan penjelasan mengenai langkah-langkah mengelola usaha serta strategi membangun bisnis yang kuat sebagai langkah pembelajaran agar para peserta memahami mengenai materi kewirausahaan. Melalui pembelajaran ini terjadi interaksi dua arah sehingga terjadi pertanyaan peserta secara kooperatif. Maka dari sinilah dapat diketahui pengalaman dan kendala yang dirasakan oleh peserta dalam menjalankan usahanya. Seperti yang dikemukan pertanyaan Ibu Marimin bagaimana cara pengelolaan usaha yang tepat agar tetap di kenal masyarakat? Maka narasumber menjawab bahwa sebaiknya adanya kemasan yang unik agar konsumen mudah mengenal hasil produksi yang kita miliki. Selanjutnya narasumber juga 
memberikan solusi penambahan alat produksi supaya nantinya ditambahkan supaya pesanan bisa dipenuhi. Selain itu juga adanya penunjuk jalan seperti Google Maps supaya konsumen mudah mendapatkan alamat rumah produksi Aloe vera Ibu Marimin.

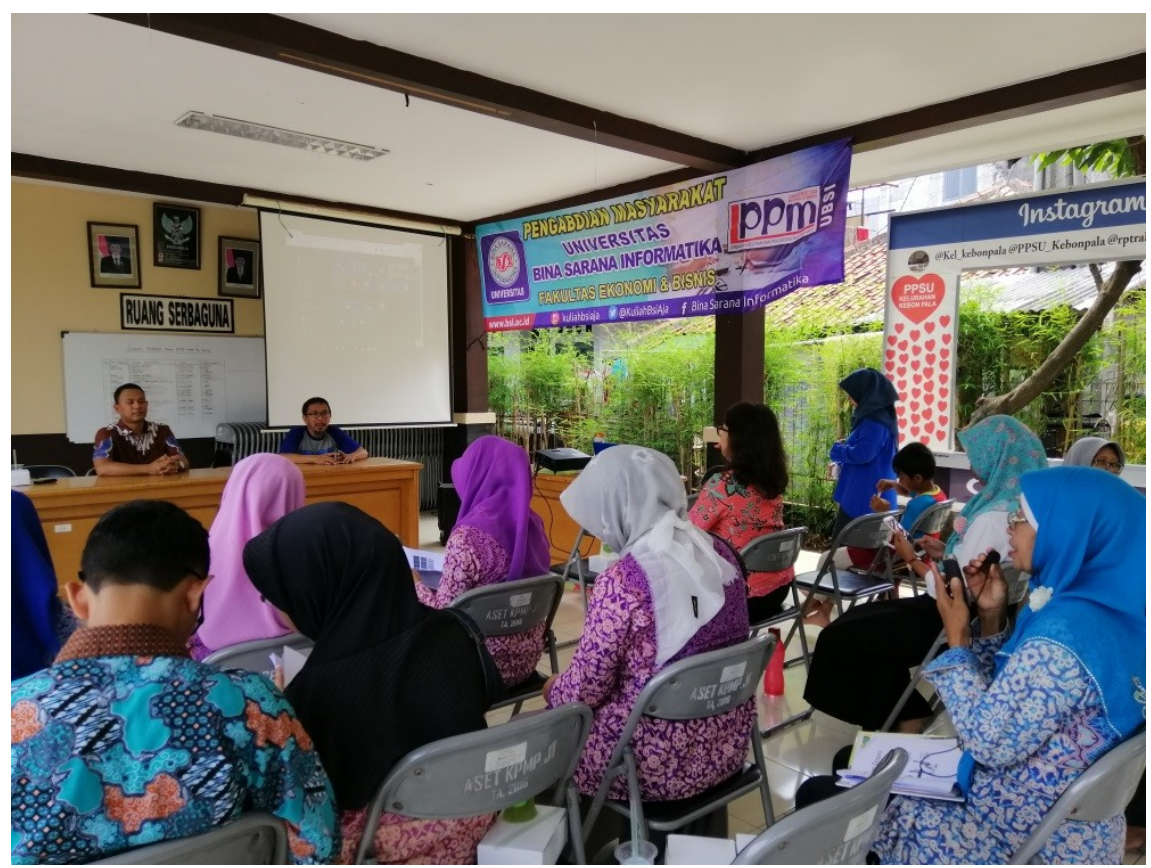

Gambar 6. Pelatihan Kewirausahaan (sesi tanya jawab)

Evaluasi kegiatan dilakukan pada saat pelatihan berlangsung dengan cara memberikan pertanyaan kepada peserta mengenai pelatihan yang dilakukan secara individu. Hal ini dilakukan untuk mengetahui bagaimana tanggapan dari peserta mengenai pelatihan kewirausahaan yang dilaksanakan. Berdasarkan pertanyaan Ibu Marimin pada pelaksanaan maka mendapatkan solusi bahwa kemasan minuman langsung minum maupun minuman instan serta makanan kecil dan sudah berlogo $\mathrm{FaFa}$ Aloe vera sehingga konsumen lebih mudah mengenalinya. Produk hasil kerajinan tangan berupa manik-manik juga tak kalah bagusnya memiliki kekhasan manik-manik yang dibentuk menjadi toples, tempat tissue serta tempat air mineral. Alat produksi seperti blender bumbu kering juga merupakan solusi agar sesuai bisa memenuhi pesanan. Selain itu adanya Google Maps supaya memudahkan konsumen mengetahui tempat produksinya.

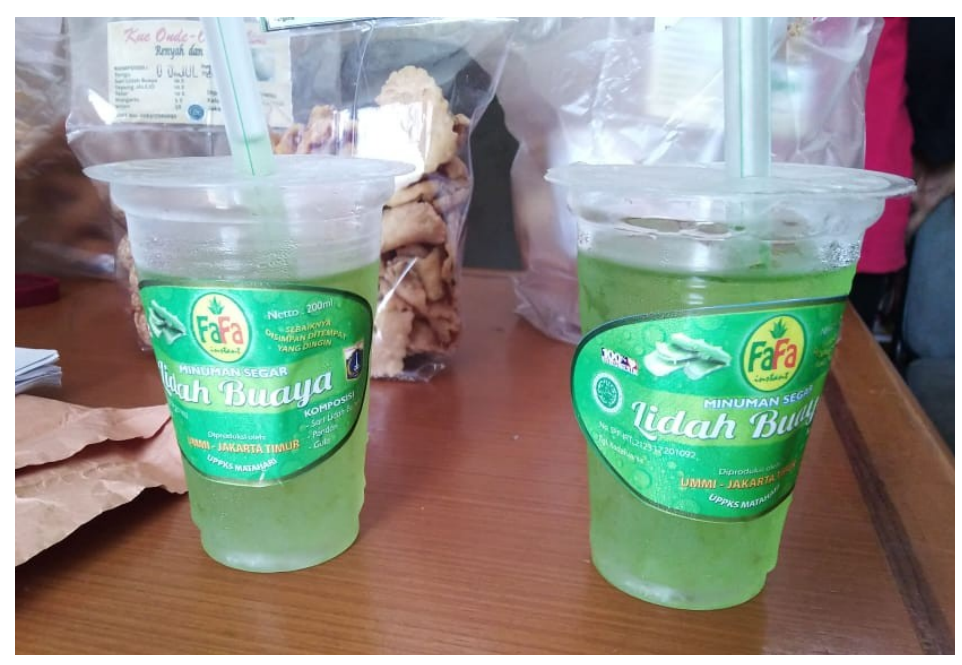

Gambar 7. Minuman Aloe vera 


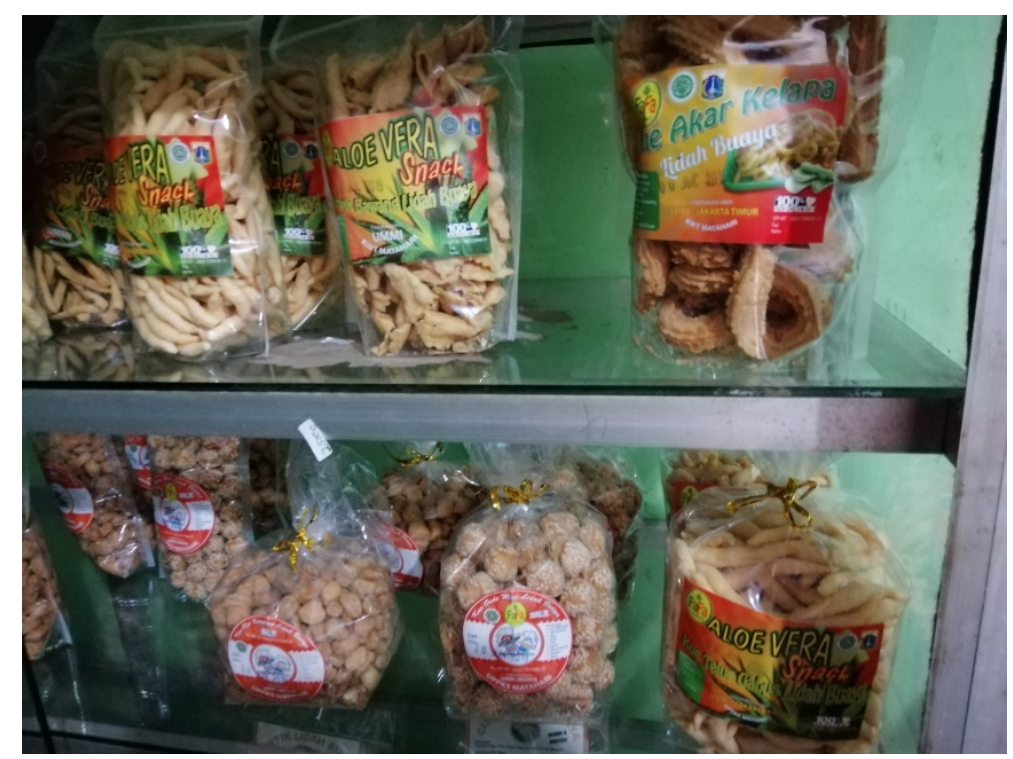

Gambar 8. Makanan Kecil Terbuat dari Aloe vera

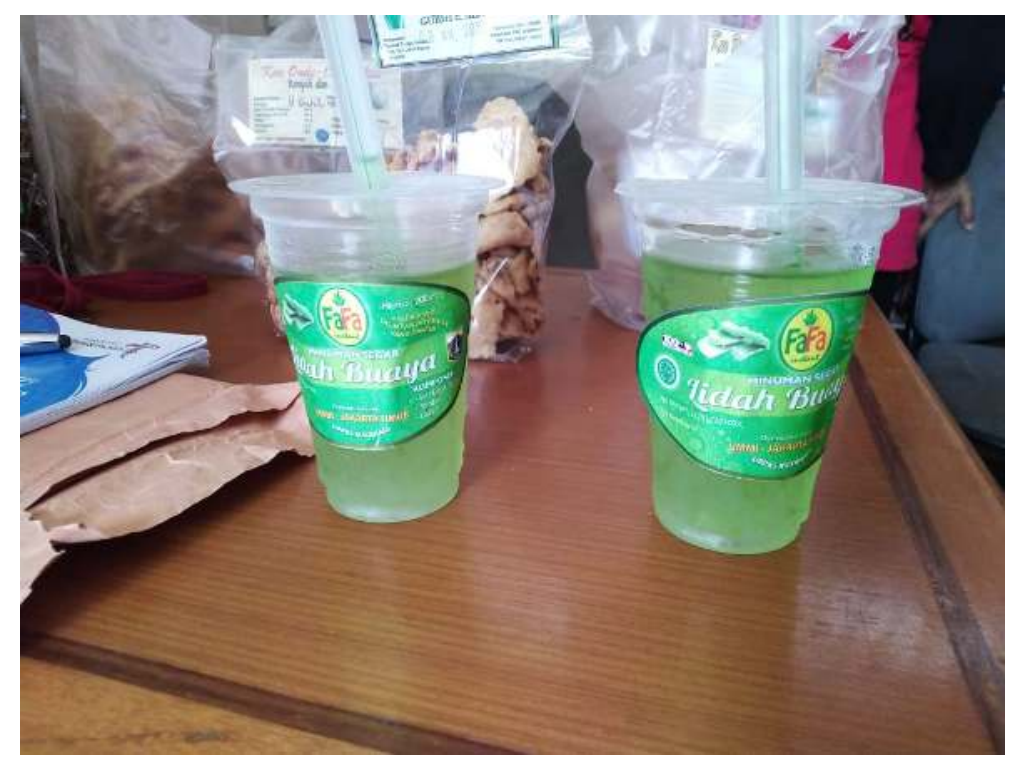

Gambar 9. Minuman Instan Aloe vera

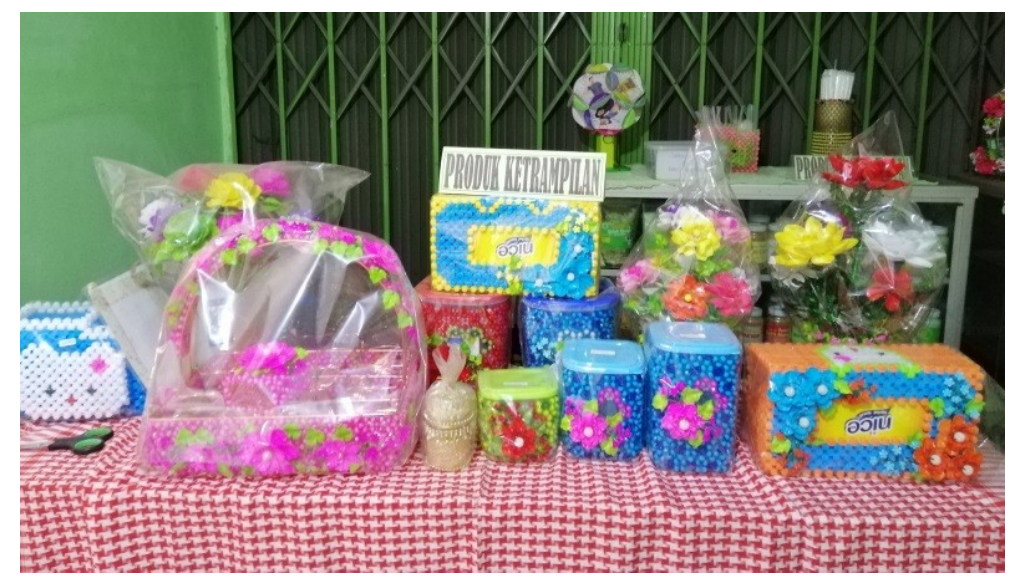

Gambar 10. Ketrampilan Manik-Manik 


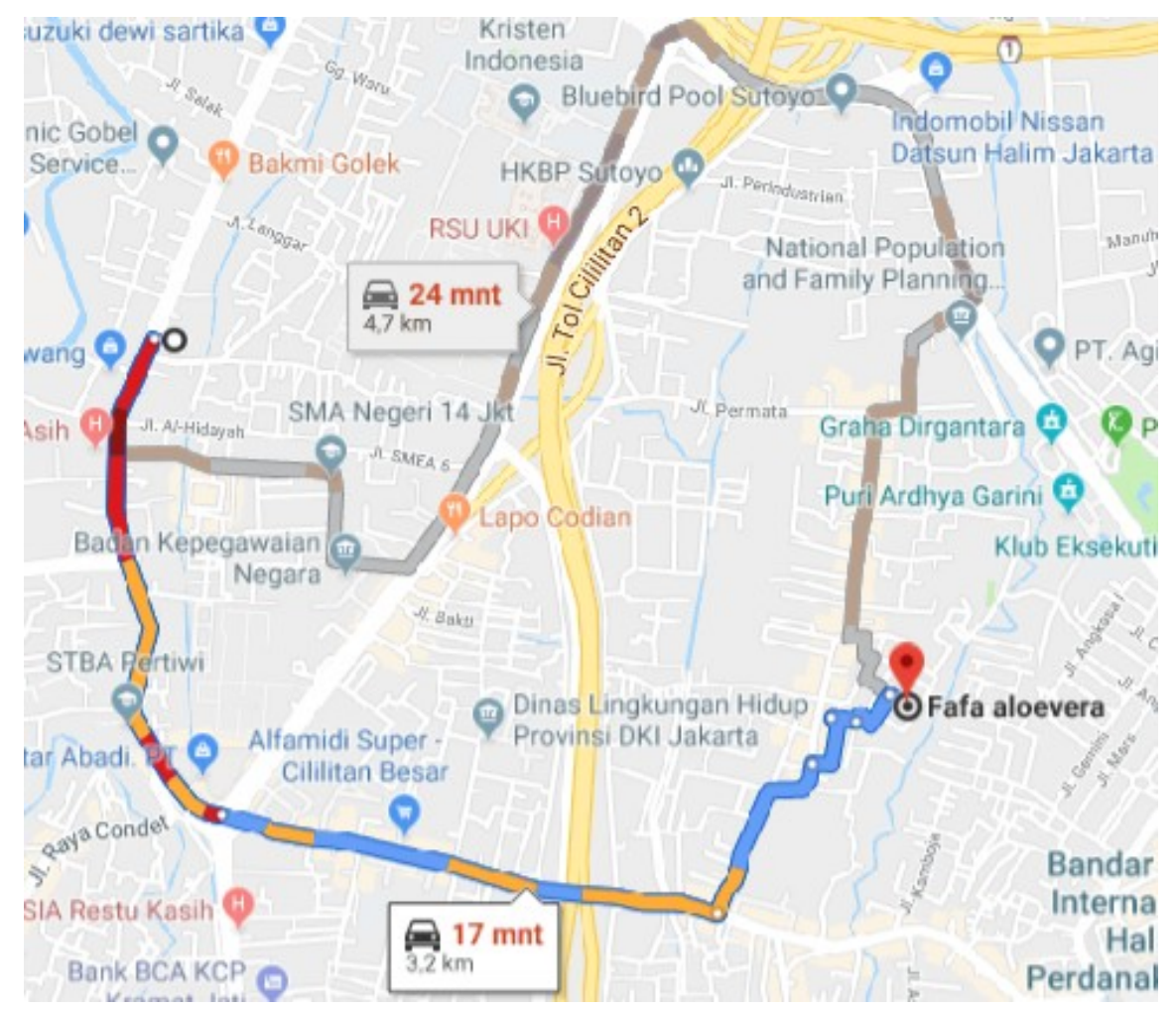

Gambar 11. Google Maps Fafa Aloevera

Setelah pelaksanaan pelatihan, tim pengabdian masyarakat menyebarkan kuesioner ke peserta untuk mengetahui antusiasme dari peserta.

Tabel 1. Hasil Kuesioner Pelatihan Kewirausahaan

\begin{tabular}{llrrrr}
\hline No. & Kriteria & $\begin{array}{c}\text { Bobot } \\
\text { Nilai }\end{array}$ & $\begin{array}{c}\text { Jumlah } \\
\text { Pilihan }\end{array}$ & Skor & $\begin{array}{c}\text { Persentase } \\
(\%)\end{array}$ \\
\hline 1 & Sangat Tidak Paham & 1 & 0 & 0 & 0 \\
2 & Tidak Paham & 2 & 0 & 0 & 0 \\
3 & Cukup Paham & 3 & 4 & 12 & 10 \\
4 & Paham & 4 & 23 & 92 & 77 \\
5 & Sangat Paham & 5 & 3 & 15 & 13 \\
\hline & \multicolumn{1}{c}{ Total } & & 30 & 119 & 100 \\
\hline
\end{tabular}

Hasil kuesioner menunjukkan bahwa peserta memahami pelatihan kewirausahaan yang diadakan. Hal ini menggambarkan bahwa peserta memiliki respon positif terhadap pelatihan tentang kewirausahaan yang diberikan.

\section{KESIMPULAN}

Kesimpulan dari PKM yang dilakukan adalah:

1. Pelatihan tentang kewirausahaan sangat membantu pelaku UKM di RPTRA Kebon Pala Berseri untuk mengembangkan usaha.

2. Pelaku UKM dapat meningkatkan pengetahuan tentang kewirausahaan.

3. Pendampingan terhadap UKM sangat membantu UKM dalam menerapkan pengetahuan yang diperoleh selama pelatihan berlangsung. 


\section{UCAPAN TERIMA KASIH}

Kegiatan PKM ini mendapat dukungan dari beberapa pihak baik secara morel maupun materiel. Oleh sebab itu, penulis mengucapkan terima kasih kepada:

1. Kemenristekdikti yang telah mengadakan Hibah Pengabdian Masyarakat dengan skema Program Kemitraan Masyarakat Pendanaan Tahun 2019.

2. LPPM Universitas Bina Sarana Informatika.

3. Kelurahan Kebon Pala Berseri dan masyarakat, khususnya UKM yang telah mendukung program PKM ini.

\section{DAFTAR PUSTAKA}

Ariani, \& Utomo, M. N. (2017). KAJIAN STRATEGI PENGEMBANGAN USAHA MIKRO KECIL DAN MENENGAH (UMKM) DI KOTA TARAKAN. Jurnal Organisasi Dan Manajemen, 13(2), 99-118.

Hamid Edy Suandi \& Susilo Y. Sri. (2011). Strategi pengembangan usaha mikro kecil dan menengah di provinsi daerah istimewa Yogyakarta. Jurnal Ekonomi Pembangunan, 12(1), $45-55$.

Irdayanti. (2012). Peran pemerintah dalam pengembangan UKM berorientasi ekspor studi kasus: Klaster kasongan dalam rantai nilai tambah global. Peran Pemerintah Dalam Pengembangan UKM Berorientasi Ekspor Studi Kasus: Klaster Kasongan Dalam Rantai Nilai Tambah Global, 3(2).

Sakur. (2011). Kajian faktor-faktor yang mendukung pengembangan usaha mikro kecil dan menengah. Spirit Publik, 7(2), 85-110.

Syahza, A. (2013). Pengembangan Usaha Kecil dan Menengah (UKM) untuk percepatan peningkatan ekonomi daerah di Kabupaten Indragiri Hulu Propinsi Riau, Pusat Pengkajian Koperasi dan Pemberdayaan Ekonomi Masyarakat. Riau: Pusat Pengkajian Koperasi dan Pemberdayaan Ekonomi Masyarakat. 
JPP IPTEK, Mei 2019, Vol. 3, No. 1

- Halaman ini sengaja dikosongkan - 